\section{A Review of Empirical Literature on Maternal Factors and Child Malnutrition}

Sri Lanka Journal of Social Sciences and Humanities Volume 1 Issue 2, August 2021: 59-68 ISSN: 2773 692X (Online), 27736911 (Print) Copyright: (C) 2021 The Author(s)

Published by Faculty of Social Sciences and Languages, Sabaragamuwa University of Sri Lanka Website: https://www.sab.ac.lk/sljssh DOI: http://doi.org/10.4038/sljssh.v1i2.38

\author{
Rathnayake, R.M.L. ${ }^{1,}{ }^{*}$, Semasinghe, W.M. ${ }^{2}$ and Gunathilake, M.M. ${ }^{2}$ \\ ${ }^{1}$ Department of Economics and Statistics, Sabaragamuwa University of Sri Lanka, Belihuloya, 70140, Sri Lanka. \\ 2 Department of Economics, University of Kelaniya, 11600, Sri Lanka.
}

Received: 10 December, 2020, Revised: 13 March, 2021, Accepted: 24 April, 2021

How to cite this Article: Rathnayake, R.M.L., Semasinghe, W.M. and Gunathilake, M.M. (2021). A review of empirical literature on maternal factors and child malnutrition. Sri Lanka Journal of Social Sciences and Humanities, 1(2), 59-68.

\begin{abstract}
Malnutrition is a health complication leading to the downward economic development of any country. Children are the crucial group more prone to suffer from malnutrition than the other groups in the malnutrition circle. Identifying the different maternal factors affecting for child malnutrition is an important step in the process of reducing child malnutrition. The objective of this study is to accomplish a review of the empirical literature on maternal factors and child malnutrition by analyzing past empirical literature. The judgment sampling technique was utilized to select a sample of 40 research articles on the relationship between various factors and child malnutrition and the articles with the maternal factors were filtered and reviewed. Analyzing the data was achieved through the use of descriptive statistics and content analysis. The results found that more than $75 \%$ of journal articles reviewed have discussed the maternal factors affecting child malnutrition. Mothers' Education, Mothers' Breastfeeding practice, Maternal Health, Age of Mother (the current age of mother and mother's age at pregnancy), BMI of mother, Mothers' Employability and Mass Media expose are the most important maternal factors related to child malnutrition. The finding of this study suggests the future researchers study the maternal factors and child malnutrition focusing on school children since they were paid less attention by the reviewed research studies. The results may be a guide for future researchers and scholars who are interesting in the issue and may inform the health sector where effective future intervention should be improved to overcome the incidence of child malnutrition.
\end{abstract}

Keywords: Empirical literature, Historical approach, Malnutrition, Maternal factors, Research articles

\section{INTRODUCTION}

Malnutrition is a health complication leading to downward of economic development of any country. Today it has become a major global challenge nevertheless many other indicators such as life expectancy and literacy rate are well achieved. According to World Health Organization (WHO) (2020), malnutrition is a situation caused by prevailed deficiencies, excesses, or imbalances in a person's intake of energy and/or nutrients. Children are the crucial group more prone to suffer from malnutrition than the other groups in the malnutrition circle. WHO (2020) estimated that globally, 144.0 million of children under 5 are suffering from stunting, 47.0 million and 14.3 million of children under 5 are affected by wasting and severe wasting respectively while 38.3 million are overweight? Annually, more than 3 million preventable child deaths occurred due to undernutrition (Cunningham et al., 2015). Efficient labor supply and economic development depend on a healthier nation and reducing child malnutrition is a very important and essential requirement to achieve this goal. Identifying the different maternal factors affecting for child malnutrition is an important step in the process of reducing or combating child malnutrition. Many researchers have conducted their research on the diverse maternal and other factors affecting for child malnutrition. Plenteous research papers have been published on this issue in the past by many countries in the world (eg: Demissie and Worku, 2013; Fagbamigbe et al., 2020; Hannah et al., 2017; Sargana and Mohyuddin, 2013; Magalhães and Clements, 2011; Yadav and Dixit, 2017). As an area of investigation, this has achieved enormous recognition among researchers. However, the main barrier to studying the various maternal factors that affecting for child malnutrition is the unavailability of a consistent theoretical framework or logic to guide for identifying the relationship. Generally, the relationship between maternal socioeconomic and health factors and child malnutrition is obvious. Maternal factors sturdily affect child malnutrition and finally long-term health complications. Maternal factors had significant effects on both severe and moderate malnutrition among children aged 0-59 months in Bangladesh (Rahman et al., 2009). However, the studies on investigating the maternal factors that affect for child malnutrition by reviewing past empirical studies are rare to find. The objective of this study is to accomplish a review of the empirical literature on maternal factors and child malnutrition by analyzing past empirical literature from 2005 to 2020. A review of literature of what has accomplished in the past on maternal factors and child malnutrition may direct the future researchers and scholars who are interesting in the area and may inform the health

\footnotetext{
* Corresponding author: Tel.: +94 (71) 568 9664; Email: rathna@ssl.sab.ac.lk

iD https://orcid.org/0000-0002-2243-1480
} 
sector and other authorities where the effective future intervention should be improved to overcome the incidence of child malnutrition.

\section{THEORETICAL BACKGROUND}

A literature review means summarizing and evaluating a body of existing knowledge relating to a specific topic (Knopf, 2006; McCombes, 2019). The term literature refers to the available knowledge of a particular area of investigation of any discipline while the term 'review' means the assessment or evaluation. Literature Review is the evaluation of the available knowledge in the field of investigation in a unique way to identify research gaps which provide the rationale for the study. Literature review is conducted mainly under three types such as empirical literature, theoretical literature and methodological literature. The study attempts to review empirical literature relating to the maternal factors and child malnutrition. An empirical literature review is more commonly called a systematically examine the past empirical studies to answer a particular research question (Gohavacyf (Blog), 2020). Malnutrition refers to both undernutrition and over-nutrition (Das and Gulshan, 2017). Child malnutrition may be defined as a pathological state resulting from inadequate nutrition, including undernutrition (protein-energy malnutrition) due to insufficient intake of energy and other nutrients; overnutrition (overweight and obesity) due to excessive consumption of energy and other nutrients; deficiency diseases due to insufficient intake of one or more specific nutrients such as vitamins or minerals (Ge and Chang, 2001). Malnutrition continues as a circle and child malnutrition is predominant in this vicious cycle.

\section{Figure 1: Malnutrition cycle}

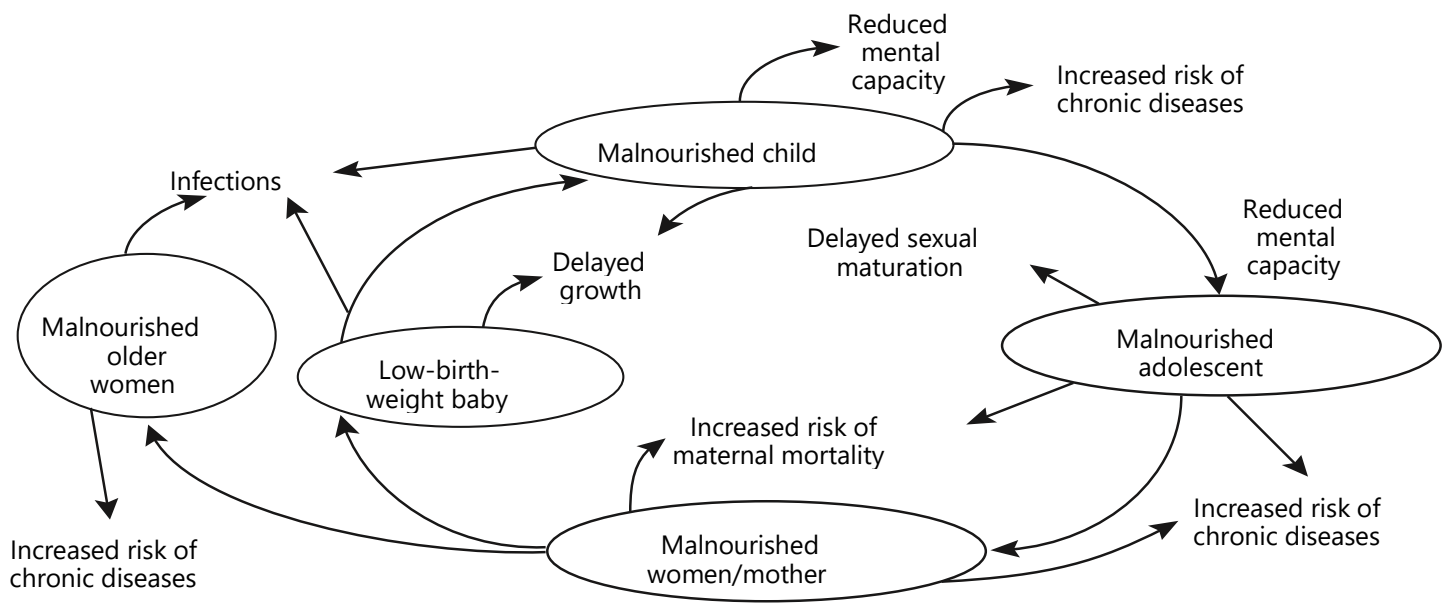

Source: Dasa, Lassib, Hoodbhoya, and Salama, 2018.

According to figure 1 , when the malnourished mothers deliver baby with low birth weight, low birth weight baby becomes malnourished child with his or her growing and may suffer from this situation continuously due to some reasons such as poor economic status of family, low educational level of parents while some may recover from the situation. With the insufficient growth, when children become adolescents, they continue the malnutrition situation, as this going through out the cycle. It is associated with low mental capacity of the child. When the child is growing up as female, this situation leads to continue the malnutrition among pregnant mothers. As a result, malnourished mothers may give birth to a baby with low weight. As malnutrition mothers give birth to low-birth-weight babies, it goes throughout their lives. And also, women who are undernourished are at a higher risk of dying at the pregnancy or giving birth prematurely. If young men and women don't recover from malnutrition at their young age, they may suffer from malnutrition continuously and leading to elderly malnutrition and it remain until they die creating very adverse effects to any country in its development process.

Different types of factors are responsible for child malnutrition. Demographic factors, health factors, social factors, geographical factors and economic factors are well identified among them. Rahman and Chowdhury (2007) pointed out that the demographic characteristics are existing as the key significant factor for chronic malnutrition in the study of determinants of chronic malnutrition of preschool children in
Bangaladesh. According to Fagbamigbe et al. 2020, healthcare services is a main attribute to the nutritional status of urban children. Yadav and Dixit (2017) indicated that a significant association between socioeconomic status of parents and the nutritional status of children. Rahman and Chowdhury (2007) has showed that regional differentials were significantly associated with severe as well as moderate stunting. According to Zhang et al. (2016), household economic status was a significant factor for malnutrition among children.

Many researchers have paid the attention for maternal factors through all these demographic, health, social, geographical and economic areas. Generally, the relationship between maternal socioeconomic and health factors and child malnutrition is obvious. Maternal factors sturdily affect child malnutrition and finally long-term health complications. According to Rahman et al. (2009), maternal factors had significant effects on both severe and moderate malnutrition among children. However, the separate studies focusing directly the maternal factors are limited. The main barrier to studying the various maternal factors affecting for child malnutrition is the unavailability of a consistent theoretical framework or logic to guide for identifying the relationship. However, the studies on investigating the maternal factors that affect for child malnutrition by reviewing past empirical studies are rare to find which is a huge gap in the literature. 


\section{METHODOLOGY}

This study was based on the historical approach of reviewing past empirical literature on the maternal factors and child malnutrition which was filtered from the research articles on the different factors and child malnutrition. A research article is the sampling unit of analysis in this study. A sample of 40 research articles published from 2005 to 2020 was selected for getting reviewed. Since the sampling frame is unavailable and the entire population is inaccessible judgment sampling technique belonged to non-probability sampling methods was employed in selecting research articles for the sample. The electronic search was directed to search for studies used in this review by searching internet resources. The selected articles have been published in different kinds of journals. Many countries have been investigated by researchers. Case studies research articles were not considered in this study.

Data entering and data processing was the initial step for data analysis. By investigating the research papers, important points were summarized in an excel sheet. The rows were arranged for research articles while the columns were arranged for their important points. This summary includes name of author, year of publication, name of the journal, country investigated, sample size, data types, analytical approach, unit of analysis, measurement of malnutrition and maternal factors used as independent variables such as Mother's Education Mother's Breastfeeding, Maternal Health, Age of Mother (current age of mother and mother's age at pregnancy), BMI of mother, Mothers' Employability, Mass Media expose of mother and Marital Status. Data analysis was achieved using descriptive statistics and content analysis. Considering the key characteristics of the sample of research articles, size of the sample, unit of analysis, data collection method, analytical approach and statistical tests, year of publication, type of journal, country investigated are important. The minimum and maximum sample size of primary data-based studies of reviewed articles were 85 and 1792 respectively. The majority, $65 \%$ of these studies reported sample sizes of over 300 . All reviewed articles here have used the child as the unit of analysis. However, $80 \%$, the majority of studies has paid their attention to the group of children under five years while only $20 \%$ was about school age children. Considering the Sri Lankan context, only $12.5 \%$ of studies have investigated Sri Lanka. Besides, only one study has paid attention to school children in the plantation

Table 1: Indices applied to measure malnutrition

\begin{tabular}{ll}
\hline Index & Reference \\
\hline BMI & $\begin{array}{l}\text { Galgamuwa et al. (2017); Getaneh et al. (2019); Igbokwe et al. (2017); Kulaga et al. (2010); Tette et al. } \\
\text { (2016); Zhang et al. (2016) }\end{array}$ \\
\hline WFH & $\begin{array}{l}\text { Ahsan et al. (2017); Fagbamigbe et al. (2020); Habyarimana et al. (2016); Jayawardena (2015); Keerthiwansa } \\
\text { et al. (2014); Pravana et al. (2017); Rahman et al. (2009) }\end{array}$ \\
\hline WFA & $\begin{array}{l}\text { Cheah et al. (2010); Chowdhury et al. (2018); Das and Gulshan (2017); Demissie, and Worku (2013); Hannah, } \\
\text { et al. (2017); Justice Moses et al. (2015); Kabir et al. (2018); Sargana, and Mohyuddin (2013); Yadav and Dixit } \\
\text { (2017) }\end{array}$ \\
\hline HFA & $\begin{array}{l}\text { Duru et al. (2015); Gebre et al. (2019); Kandala et al. (2011); Khan and Mohanty (2018); Linnemayr et al. } \\
\text { (2008); Mustari et al. (2017); Oliveira Assis et al. (2007); Rahman and Chowdhury (2007); Rathnayake and }\end{array}$ \\
\hline MUAC & Ayana et al. (2015); Dodos et al. (2018); Ghimire et al. (2020); Hossain et al. (2020) \\
\hline CIAF & Ali Khan and Azid (2011); Endris et al. (2017 \\
\hline $\begin{array}{l}\text { New In- } \\
\text { dex }\end{array}$ & Debnath and Bhattacharjee (2014) \\
\hline
\end{tabular}

Source: Literature survey, 2020 community in Sri Lanka. The articles reviewed here have employed both primary and secondary data sources. The majority of researchers, $57.5 \%$ have conducted their research based on primary data while $42.5 \%$ have conducted using secondary data. Considering the analytical approach, $58 \%$ of the research studies have employed binary or multivariate logistic regression techniques. Besides, various types of approaches such as the t-test, chi-square test, ANOVA, discriminant analysis, log linear model, and structural equation were also used.

Considering the year of publication, the highest percentage of research articles (22.5\%) in the sample have been published in 2017. More than $75 \%$ of reviewed papers belonged to the immediate last ten years, from 2011 to 2020 . The selected articles have been published in different kinds of journals. The majority of selected articles have come from some of the most popular medical journals including, American Journal of Public Health Research, BioMed Research International, Global Health, Science Journal of Public Health, BMC Nutrition, Annual Nutrition Metab, Rural and Remote Health, Maternal and child nutrition, Journal of Tropical Pediatrics among others such as Tropical Agricultural Research studies have been conducted in many countries in the world. A majority, $60 \%$ out of 40 studies reviewed here, has been conducted in Asian countries. Therefore, the determinants investigated are more applicable to work out in Asian countries. The second place has been obtained by African countries recording $35 \%$. Besides, an important contribution has been made by studying European countries and American countries too.

\section{RESULTS AND DISCUSSION}

There have been numerous research articles published on the maternal and other factors affecting for child malnutrition and reviewing them convinces to identify what has accomplished in the past research studies on the maternal factors affecting for child malnutrition.

\section{Child Malnutrition}

The variable, incidence of child malnutrition has played the key role in the discussion made through these reviewed articles as the dependent variable. Different types of measurements for indicating child malnutrition were applied as the dependent variable as given in the table 1. and International Journal of Social Economics. The selected 
Usually, there have been three methods to assess health or nutritional status representing anthropometric indicators, biochemical indicators, and clinical indicators. Among them, anthropometric measurement is the most popular, common, and easy assessment of the health and nutritional sta- tus of children. With international consistency, anthropometric indicators advocated to measure malnutrition are Birth Weight: malnutrition at birth, Weight for Age (WFA): underweight, Height for Age (HFA): stunting, Weight for Height (WFH): wasting, and body mass index.

Table 2: Percentages of each indices applied to measure malnutrition

\begin{tabular}{lrrrrrr}
\hline Index & BMI & WFH & WFA & HFA & MUAC & Others \\
\hline Count & 6 & 7 & 9 & 11 & 4 & 3 \\
Percentage & 15 & 17.5 & 22.5 & 27.5 & 10 & 7.5 \\
\hline
\end{tabular}

Source: Literature survey, 2020

Table 2 shows that the highest percentage, approximately $28 \%$ of researches studies have measured malnutrition in terms of HFA. It is noticeable that three indices, HFA, WFA and WFH are dominating in the context.

\section{Maternal Factors}

Table 3 shows the different maternal factors employed in the reviewed articles and they are treated as independent variables. The key attention of this study has been paid for

reviewing those maternal factors that influence child malnutrition and they were filtered and reviewed from the research articles on various demographic, socioeconomic, health and geographical determinants on child malnutrition. From the reviewed research articles on determinants of child malnutrition, maternal factors have been studied by $83 \%$. It shows the importance of the maternal factors in determining child malnutrition.

Table 3: Maternal Factors investigated by reviewed research articles

\begin{tabular}{|c|c|}
\hline Maternal Factors & Reference \\
\hline Mother's Education (ME) & $\begin{array}{l}\text { Ahsan et al. (2017); Ali Khan and Azid (2011); Ayana et al. (2015); Chowdhury et al. (2018); } \\
\text { Das, and Gulshan (2017); Dodos et al. (2018); Duru et al. (2015); Endris et al.(2017); Gal- } \\
\text { gamuwa et al. (2017); Getaneh et al. (2019); Ghimire et al. (2020); Habyarimana et al. } \\
\text { (2016); Igbokwe et al. (2017); Jayawardena (2015); Keerthiwansa et al. (2014); Linnemayr } \\
\text { et al. (2008); Mustari et al. (2017); Pravana et al. (2017); Rathnayake and Weerahewa } \\
\text { (2005); Tette et al. (2016); Zhang et al. (2016) }\end{array}$ \\
\hline $\begin{array}{l}\text { Mother's Breastfeeding } \\
\text { (BF) }\end{array}$ & $\begin{array}{l}\text { Ahsan et al. (2017); Ayana et al. (2015); Cheah et al. (2010); Debnath and Bhattacharjee } \\
\text { (2014); Dodos et al. (2018); Gebre et al. (2019); Ghimire et al. (2020); Hossain et al. (2020); } \\
\text { Jayawardena (2015); Justice Moses et al. (2015); Pravana et al. (2017); Rahman and Chow- } \\
\text { dhury (2007); Ubeysekara et al. (2015) }\end{array}$ \\
\hline Maternal Health (MH) & $\begin{array}{l}\text { Das and Gulshan (2017); Debnath and Bhattacharjee (2014); Dodos et al. (2018); Rahman } \\
\text { and Chowdhury (2007); Rahman et al. (2009); Tette et al. (2016); }\end{array}$ \\
\hline Age of Mother (AM) & $\begin{array}{l}\text { Getaneh et al. (2019); Habyarimana et al. (2016); Kabir et al. (2018); Pravana et al. (2017); } \\
\text { Tette et al. (2016) }\end{array}$ \\
\hline Mothers' BMI (BMI) & $\begin{array}{l}\text { Aheto et al. (2015); Habyarimana et al. (2016); Khan and Mohanty (2018); Rahman and } \\
\text { Chowdhury (2007); Tette et al. (2016) }\end{array}$ \\
\hline $\begin{array}{l}\text { Mothers' Employability } \\
\text { (MEM) }\end{array}$ & $\begin{array}{l}\text { Das and Gulshan (2017); Duru et al. (2015); Galgamuwa et al. (2017); Keerthiwansa et al. } \\
\text { (2014); Ubeysekara et al. (2015) }\end{array}$ \\
\hline Mass Media expose (MM) & $\begin{array}{l}\text { Keerthiwansa et al. (2014); Rahman and Chowdhury (2007); Rahman et al. (2009); Tette et } \\
\text { al. (2016) }\end{array}$ \\
\hline Marital Status (MS) & Dodos et al. (2018); Tette et al. (2016) \\
\hline Others & $\begin{array}{l}\text { Ahsan et al. (2017); Ayana et al. (2015); Cheah et al. (2010); Debnath and Bhattacharjee, } \\
\text { (2014); Dodos et al. (2018); Endris et al. (2017); Fagbamigbe et al. (2020); Justice Moses et } \\
\text { al. (2015); Oliveira Assis et al. (2008); Rahman and Chowdhury (2007) }\end{array}$ \\
\hline
\end{tabular}

Source: Literature survey, 2020

According to the empirical literature, maternal profile includes Mother's Education (ME), Mother's Breastfeeding $(B F)$, Maternal Health (MH), Age of Mother (AM) (current age of mother and mother's age at pregnancy), BMI of mother (BMI), Mothers' Employability (MEM), Mass Media Figure 2: Percentages of maternal factors investigated expose (MM) Marital Status (MS) and others.

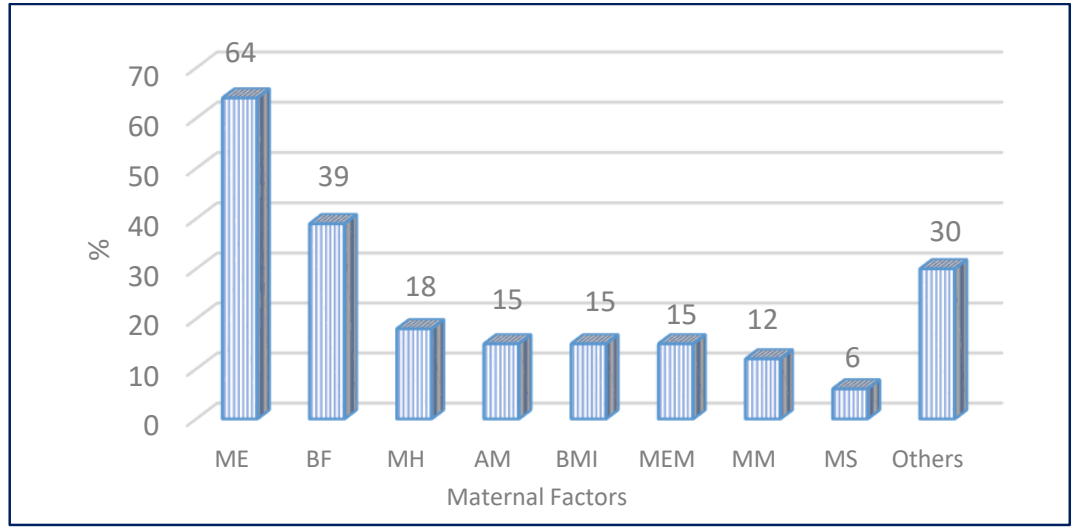

Source: Literature survey data, 2020 
Figure 2 shows the percentages of research articles of different maternal factors from the total research articles that investigated maternal factors. Maternal education was key factor investigated by the majority of the research articles. Mother's Breastfeeding practice has received the second place. Other group includes times of pregnancy and early pregnancy, place of delivery, birth interval, family planning,

Table 4 Mothers' Education and Child Malnutrition

\begin{tabular}{|c|c|c|}
\hline Reference & Study/Variable & Results \\
\hline Ahsan et al. (2017) & illiteracy of mother & $\begin{array}{l}\text { more likely to be malnourished than child of } \\
\text { a literate mothers }\end{array}$ \\
\hline Ali Khan and Azid (2011) & mothers' education, & $\begin{array}{l}\text { play an important role for child's nutritional } \\
\text { status }\end{array}$ \\
\hline Ayana et al. (2015) & maternal education & $\begin{array}{l}\text { significant relationship with nutritional sta- } \\
\text { tus as measured by wasting. }\end{array}$ \\
\hline Chowdhury et al. (2018) & $\begin{array}{l}\text { Completed and in completed sec- } \\
\text { ondary education for mothers }\end{array}$ & $\begin{array}{l}\text { less likely to be underweight than unedu- } \\
\text { cated mothers who had no formal schooling }\end{array}$ \\
\hline Das and Gulshan (2017) & no or primary education of mother & $\begin{array}{l}\text { key factors for malnutrition in both terms of } \\
\text { stunting and underweight }\end{array}$ \\
\hline Dodos et al. (2018) & $\begin{array}{l}\text { educational status of caretaker (did } \\
\text { not attend any school) }\end{array}$ & $\begin{array}{l}\text { increased the sever acute malnutrition } \\
\text { among children. }\end{array}$ \\
\hline Duru et al. (2015) & no formal education for mothers & underweight was highest among children. \\
\hline Endris et al. (2017) & education of mother & $\begin{array}{l}\text { independent relationship with nutritional } \\
\text { status of children }\end{array}$ \\
\hline Galgamuwa et al. (2017) & being an educated mother & $\begin{array}{l}\text { an important factor associated with under- } \\
\text { nutrition }\end{array}$ \\
\hline Getaneh et al. (2019) & No formal education for mothers & $\begin{array}{l}\text { probability of getting thin was lesser than } \\
\text { mothers had secondary and above educa- } \\
\text { tion. }\end{array}$ \\
\hline \multirow[t]{2}{*}{ Ghimire et al. (2020) } & $\begin{array}{l}\text { Illiteracy of mother } \\
\text { (unadjusted logistics regression } \\
\text { model) }\end{array}$ & $\begin{array}{l}\text { significant predictor of severe acute malnu- } \\
\text { trition }\end{array}$ \\
\hline & $\begin{array}{l}\text { mother's education level (adjusted } \\
\text { model) }\end{array}$ & $\begin{array}{l}\text { no relationship with severe acute malnutri- } \\
\text { tion }\end{array}$ \\
\hline Habyarimana et al. (2016) & $\begin{array}{l}\text { mother's education level and } \\
\text { knowledge of nutrition by mother }\end{array}$ & $\begin{array}{l}\text { key determinants of malnutrition of chil- } \\
\text { dren }\end{array}$ \\
\hline Igbokwe et al. (2017) & maternal education. & $\begin{array}{l}\text { significant statistical influence on the nutri- } \\
\text { tional status of children }\end{array}$ \\
\hline Jayawardena (2015) & $\begin{array}{l}\text { Mother's having below primary ed- } \\
\text { ucation }\end{array}$ & $\begin{array}{l}\text { significantly higher risk of long- term growth } \\
\text { failure }\end{array}$ \\
\hline Keerthiwansa et al. (2014) & lower maternal education & associated with severe acute malnutrition \\
\hline Linnemayr et al. (2008) & $\begin{array}{l}\text { female education at the primary } \\
\text { level }\end{array}$ & positive impact on nutrition. \\
\hline Mustari et al. (2017) & education of caretakers & linked to child malnutrition \\
\hline Pravana et al. (2017) & mother's educational level & $\begin{array}{l}\text { not significantly associated with severe } \\
\text { acute malnutrition }\end{array}$ \\
\hline $\begin{array}{l}\text { Rathnayake and Weerahewa } \\
(2005)\end{array}$ & being a not well- educated mother & children are under nourished \\
\hline Tette et al. (2016) & $\begin{array}{l}\text { mother's education level and } \\
\text { mother's literacy }\end{array}$ & related with malnutrition \\
\hline Zhang et al. (2016) & maternal education & $\begin{array}{l}\text { protective factor to decrease risk of under- } \\
\text { nutrition }\end{array}$ \\
\hline
\end{tabular}

family headed by mother, women's decision-making autonomy and having health insurance.

Mothers' Education and Child Malnutrition: Mothers' Education is an important maternal factor. According to figure 2 , from the reviewed articles that investigated maternal factors, Mothers' Education has been studied by $64 \%$ and for $95 \%$ of them the relationship was found to be significant.

Source: Literature survey, 2020

As given in the table 4, Getaneh et al. (2019), Chowdhury e al. (2018), Igbokwe et al. (2017), Das and Gulshan (2017), Endris et al. (2017), Tette et al (2016), Habyarimana et al. (2016), Duru et al. (2015), Ayana et al. (2015), Ali Khan and Azid (2011) concluded that there is a relationship between mother's education level and child malnutrition. Ahsan et al. (2017) and identified that illiteracy of mother as a significant factor influenced the prevalence of stunting and child of an illiterate mother was more likely to be malnourished than a child of literate mothers. Ghimire et al. (2020) too pointed out that illiteracy of mother is a significant predictor of severe acute malnutrition. Dodos et al (2018) and Mustari et al. (2017) demonstrated that the education of caretakers is linked to child malnutrition. Linnemayr et al. (2008) foundevidence of a positive impact of female education on utrition and Zhang et al. (2016) showed that maternal education as a protective factor to decrease risk of undernutrition.

Considering Sri Lanka, Rathnayake and Weerahewa (2005) found that mothers of undernourished children are not well educated. Keerthiwansa et al. (2014) examined that having malnutrition was associated with lower maternal education. Galgamuwa et al. (2017) and Jayawardena (2015) suggested 
that educated and knowledgeable mothers might have better practices to reduce the malnutrition of their children. In contrast, Pravana et al (2017) found that a mother's educational level was not significantly associated with severe acute malnutrition among children. Similarly, in the adjusted model, no evidence was found to have a relationship between mother's education level and severe acute malnutrition among children by Ghimire et al. (2020).

Table 5: Mothers' Breastfeeding and Child Malnutrition

\begin{tabular}{|c|c|c|}
\hline Reference & Study/Variable & Results \\
\hline Ahsan et al. (2017) & absence of breastfeeding & $\begin{array}{l}\text { significant factor influenced for preva- } \\
\text { lence of stunting }\end{array}$ \\
\hline Ayana et al. (2015) & $\begin{array}{l}\text { time of initiated breast feeding } \\
\text { and duration the child exclu- } \\
\text { sively breast fed }\end{array}$ & $\begin{array}{l}\text { significantly associated with nutritional } \\
\text { status as measured by wasting }\end{array}$ \\
\hline Cheah et al. (2010) & breast feeding & significant effects on malnutrition \\
\hline Debnath and Bhattacharjee (2014) & breast feeding practice & $\begin{array}{l}\text { the most important factor that effects } \\
\text { child malnutrition. }\end{array}$ \\
\hline Dodos et al. (2018) & $\begin{array}{l}\text { non-exclusive breastfeeding } \\
\text { during first } 6 \text { months }\end{array}$ & $\begin{array}{l}\text { significant related with sever acute mal- } \\
\text { nutrition }\end{array}$ \\
\hline Gebre et al. (2019) & Initiation of breast feeding & associated with wasting \\
\hline Ghimire et al. (2020) & $\begin{array}{l}\text { no exclusive breastfeeding } \\
\text { practices (unadjusted logistics } \\
\text { regression model) } \\
\text { exclusive breastfeeding prac- } \\
\text { tices (adjusted model) }\end{array}$ & $\begin{array}{l}\text { significant predictor of severe acute } \\
\text { malnutrition } \\
\text { no evidence was found to have a associ- } \\
\text { ation with severe acute malnutrition }\end{array}$ \\
\hline Hossain et al. (2020) & $\begin{array}{l}\text { breastfeeding duration of } \\
\text { greater than } 6 \text { months }\end{array}$ & $\begin{array}{l}\text { reduced the probability of severe acute } \\
\text { malnutrition. }\end{array}$ \\
\hline Jayawardena (2015) & breastfeeding. & low risk of malnutrition \\
\hline Justice Moses et al. (2015) & longer breastfeeding duration & increased risk of malnutrition \\
\hline Pravana et al. (2017) & $\begin{array}{l}\text { initiation of breastfeeding and } \\
\text { exclusive breastfeeding }\end{array}$ & $\begin{array}{l}\text { not significantly associated with severe } \\
\text { acute malnutrition }\end{array}$ \\
\hline Rahman and Chowdhury (2007) & breast-feeding & $\begin{array}{l}\text { significant association with both severe } \\
\text { and moderate stunting. }\end{array}$ \\
\hline Ubeysekara et al. (2015) & $\begin{array}{l}\text { duration of exclusive breast } \\
\text { feeding }\end{array}$ & no relationship with malnutrition \\
\hline
\end{tabular}

Source: Literature survey, 2020

According to the table 5 , as found by Debnath and Bhattacharjee (2014), breastfeeding practice is the most important factor that affects child malnutrition. Cheah et al. (2010) and Rahman and Chowdhury (2007) indicated that breastfeeding had significant effects on childhood malnutrition. Ayana et al. (2015) found that nutritional status as measured by wasting was significantly associated with time breastfeeding initiated and duration the child exclusively breastfed. Initiation of breast feeding was associated with wasting (Gebre et al. (2019). According to Hossain et al. (2020), breastfeeding practices for more than 6 months have reduced the likelihood of severe acute malnutrition of the children. Ghimire et al. (2020) and Dodos et al. (2018) have established a significant relationship between no exclusive breastfeeding practices and malnutrition among children. Ahsan et al. (2017) explored that absence of breastfeeding as a significant factor influenced stunting and breastfed children were less likely to be malnourished. Jaywardena (2015) pointed out that the low risk of malnutrition Table 6: Maternal Health and Child Malnutrition

\begin{tabular}{|c|c|c|}
\hline Reference & Study/Variable & Results \\
\hline Das and Gulshan (2017) & Mothers' underweight & $\begin{array}{l}\text { key factor for malnutrition in all three } \\
\text { terms of stunting, wasting and under- } \\
\text { weight. }\end{array}$ \\
\hline Debnath and Bhattacharjee (2014) & maternal health & $\begin{array}{l}\text { interrelate with wealth index to deter- } \\
\text { mine child malnutrition }\end{array}$ \\
\hline Dodos et al. (2018) & maternal undernutrition & have a high risk of getting malnutrition \\
\hline Rahman and Chowdhury (2007) & mother's height & strongly related to child malnutrition \\
\hline
\end{tabular}

during the first 6 months may also be due to the protective effect of breastfeeding.

However, Justice Moses et al. (2015) pointed out that longer breastfeeding duration increased the risk of malnutrition. Ubeysekara et al. (2015) showed that duration of exclusive breast feeding had no significant relationship with stunting, wasting or underweight. According to Pravana et al. (2017), initiation of breastfeeding, colostrum feeding, and exclusive breastfeeding were not significantly associated with severe acute malnutrition among children. Similarly, in the adjusted model, no evidence was found to have a relationship between exclusive breastfeeding practices and severe acute malnutrition among children by Ghimire et al. (2020).

Maternal Health and Child Malnutrition: Maternal health is another significant maternal factor influencing child malnutrition. A considerable contribution has been made for maternal health and it was studied by $18 \%$ of reviewed articles that investigated maternal factors according the figure 2 .
Mothers' Breastfeeding and Child Malnutrition: Mothers' Breastfeeding practice is another important maternal factor the researchers that investigated maternal factors have paid their attention to Mothers' Breastfeeding. 
Rahman et al. (2009)

Tette et al. (2016) poor maternal nutrition increased the risk of wasting.

level

complication during preg- no evidence of association with malnutrinancy tion
Source: Literature survey, 2020

Table 6 shows that that maternal health was found as a variable that interrelates with wealth index to determine child malnutrition and receiving antenatal care by mothers from a health professional causes to reduce the incidence of malnutrition (Debnath and Bhattacharjee, 2014). It further shows that having low maternal malnutrition demonstrates a low incidence of child malnutrition. Dodos et al. (2018) showed that maternal undernutrition seemed to have a high risk of getting malnutrition for their children. According to Rahman et al. (2009), poor maternal nutrition level was associated with a higher risk of wasting. Das and Gulshan (2017) found that underweight mothers as a key factor for Table 7: Age of Mother and Child Malnutrition

\begin{tabular}{|c|c|c|}
\hline Reference & Study/Variable & Results \\
\hline Getaneh et al. (2019) & age of mothers or caregivers & The risk of wasting was increasing \\
\hline Habyarimana et al. (2016) & mother's age at childbirth & key determinant of malnutrition \\
\hline Kabir et al. (2018) & $\begin{array}{l}\text { young mothers whose age is } \\
\text { less than } 20 \text { years }\end{array}$ & $\begin{array}{l}\text { more likely to have underweight and wast- } \\
\text { ing }\end{array}$ \\
\hline Pravana et al. (2017) & mother's age at birth & $\begin{array}{l}\text { significantly related with severe acute mal- } \\
\text { nutrition }\end{array}$ \\
\hline Tette et al. (2016) & $\begin{array}{l}\text { mother's current age } \\
\text { mother's age at pregnancy }\end{array}$ & $\begin{array}{l}\text { related with malnutrition. } \\
\text { related with malnutrition }\end{array}$ \\
\hline
\end{tabular}

Source: Literature survey, 2020

As given in the table 7, Pravana et al. (2017) and Habyarimana et al. (2016) revealed that mother's age at childbirth is a key determinant of malnutrition among children. In the bivariate analysis, Tette et al (2016) identified that both mother's current age and age at pregnancy have a relationship with malnutrition. According to Getaneh et al. (2019), the risk of malnutrition among children was increasing with the age of their mothers. Kabir et al. (2018) too examined those younger mothers were more prone to have a Table 8: Mothers' Body Mass Index and Child Malnutrition

$\begin{array}{ll}\text { Reference } & \text { Study/Variable } \\ \text { Aheto et al. (2015) } & \text { mothers' BMI }\end{array}$

Habyarimana et al. (2016) Khan and Mohanty (2018)

Rahman and Chowdhury (2007) Tette et al. (2016) malnourished child than their older counterparts in the study of Adivasi children age 24-59 months in Bangladesh. Mother's Body Mass Index (BMI) and Child Malnutrition: Mothers' BMI too had a significant influence on child malnutrition. Figure 2 shows that from the maternal related studies retained to the sample, $15 \%$ have debated the relationship between Mother's BMI and child malnutrition.
Source: Literature survey, 2020

According to the table 8, Khan and Mohanty (2018), Habyarimana et al. (2016), Rahman and Chowdhury (2007) illustrated that the $\mathrm{BMI}$ of the mother is a key determinant of malnutrition among children. Aheto et al. (2015) concluded that an increase in a mother's body mass index is associated with decreased childhood malnutrition. However, there was no evidence of an association between mother's $\mathrm{BMI}$ and malnutrition in both the bivariate and multivariate analyses (Tette et al., 2016).

Table 9: Mothers' Employability and Child Malnutrition

\begin{tabular}{lll}
\hline Reference & Study/Variable & Results \\
\hline Das and Gulshan (2017) & mother's occupation as phys- & key factor for malnutrition in both terms of \\
& ical labor & wasting and underweight. \\
Duru et al. (2015) & maternal occupation & $\begin{array}{l}\text { statistically significant association with nu- } \\
\text { tritional status of children }\end{array}$
\end{tabular}

Mothers' Employability and Child Malnutrition: Mothers' employability is a maternal economic factor associated with child malnutrition. From the reviewed articles that investigated maternal factors, $15 \%$ have discussed the relationship between Mothers' Employability and child malnutrition as shown in the figure 2 .

Results
negative relationship with malnutrition indicating de-
creased malnutrition was accompanied by increased body
mass Index
key determinant of malnutrition
strong and significant predictor for malnutrition in all
terms of underweight, stunting and wasting
significant association with severe and moderate stunting
no evidence of association with malnourishment
Mothers' Employability and Child Malnutrition: Mothers'
employability is a maternal economic factor associated with
child malnutrition. From the reviewed articles that investi-
gated maternal factors, $15 \%$ have discussed the relationship
between Mothers' Employability and child malnutrition as
shown in the figure 2 .

malnutrition in all three terms of stunting, wasting, and una mother's height is strongly related to child malnutrition. However, in both the bivariate and multivariate analyses, there was no evidence of an association between complicaAge of Mother and Child Malnutrition: Mothers' age is a key It was investigated by $15 \%$ from the journal articles that in vestigated maternal factors as given in the figure 2 .

shown in the figure 2 .

mothers' BMI key determinant of malnutrition

mothers' BMI strong and significant predictor for malnutrition in all mothers' BMI mothers' BMI

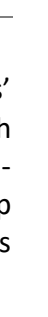

(1)


Galgamuwa et al. (2017)

Keerthiwansa et al. (2014)

Ubeysekara et al. (2015) maternal employment

Mother being a housewife mothers' unemployment an important factor associated with undernutrition

associated with severe acute malnutrition malnutrition in all terms of wasting, underweight and stunting was higher
Source: Literature survey, 2020

As revealed by the table 9, Das and Gulshan (2017) and Duru, et al (2015) have revealed that a mother's occupation is a significant factor in the nutritional status of children. Galgamuwa et al. (2017) investigated that maternal employment appeared to be an important factor associated with undernutrition among both preschool and school children in plantation community in Sri Lanka. In contrast, Ubeysekara et al. (2015) observed that malnutrition in all terms of wasting, underweight and stunting was higher among children whose mothers are unemployed than the employed mothers. Keerthiwansa et al. (2014) identified that mother being Table 10: Mass Media expose and Child Malnutrition

\begin{tabular}{lll}
\hline Reference & Study/Variable & Results \\
\hline Keerthiwansa et al. (2014) & being in socially deprived group & increases the degree of malnutrition \\
Rahman and Chowdhury (2007) & mass media exposure & strongly related to the wasting \\
Rahman et al. (2009) & mass media exposure & strongly related to the wasting \\
Tette et al. (2016) & not heard of social services & more likely to have malnutrition \\
\hline
\end{tabular}

Source: Literature survey, 2020

Mass media exposure is strongly related to the wasting of children and children whose mothers did not expose to any mass media had a higher risk of becoming acute malnourished (Rahman and Chowdhury, 2007 and Rahman et al. 2009). Tette et al. (2016) declared that mothers who not having heard of social services were more likely to have malnutrition in children than those who have heard of such services according to the bivariate analysis. In the Sri Lankan Table 11: Marital Status and Child Malnutrition a housewife cause to increase incidence of child in the study of malnutrition and anemia among hospitalized children in Vavuniya.

Mass Media expose of mother and Child Malnutrition: Mass Media expose of mother is one of the maternal social factors related to child malnutrition. The figure 2 shows that it was investigated by $12 \%$ of the reviewed articles that investigated maternal factors.

\begin{tabular}{lll}
\hline Reference & Study/Variable & Results \\
\hline Dodos et al. (2018) & $\begin{array}{l}\text { not married/ lives alone of caretakers or } \\
\text { mothers } \\
\text { being unmarried } \\
\text { being unmarried }\end{array}$ & $\begin{array}{l}\text { more likely to be severe acute malnour- } \\
\text { ished }\end{array}$ \\
Tette et al. (2016) & increases the prevalence of malnutrition
\end{tabular}

Source: Literature survey, 2020

According to Dodos et al. (2018), the marriage status of not married/ lives alone of caretakers or mothers was more likely to be severe acute malnourished compared to their counterpart. Dodos et al. (2018) and Tette et al. (2016) have observed that being unmarried increases the prevalence of context, Keerthiwansa et al. (2014) concluded that being in a socially deprived group increases the degree of malnutrition.

Marital Status and Child Malnutrition: Marital status is another significant social factor related to child malnutrition. It was investigated by $6 \%$ of the reviewed articles that investigated maternal factors. malnutrition of their children.

Table 12: Other Marital Factors and Child Malnutrition

\begin{tabular}{|c|c|c|}
\hline Reference & Study/Variable & Results \\
\hline Ahsan et al. (2017) & $\begin{array}{l}\text { Pregnancy more than four } \\
\text { times }\end{array}$ & Significant factor influenced for stunting \\
\hline Ayana et al. (2015) & place of delivery & significantly associated with wasting \\
\hline Cheah et al. (2010) & mothers' family planning & Significantly correlated with malnutrition \\
\hline Debnath and Bhattacharjee (2014) & $\begin{array}{l}\text { women's decision-making } \\
\text { autonomy }\end{array}$ & negatively associated with malnutrition \\
\hline Dodos et al. (2018) & early pregnancy & Related with sever acute malnutrition \\
\hline Endris et al. (2017) & preceding birth interval & independently associated with nutritional status \\
\hline Fagbamigbe et al. (2020) & short birth interval & affected to nutritional out come \\
\hline Justice Moses et al. (2015) & $\begin{array}{l}\text { not covered by national } \\
\text { health insurance }\end{array}$ & are associated with increased risk of malnutrition \\
\hline Oliveira Assis et al. (2008) & family headed by a woman & main determinant of child malnutrition \\
\hline Rahman and Chowdhury (2007) & Place of delivery & $\begin{array}{l}\text { significantly associated with severe as well as } \\
\text { moderate stunting }\end{array}$ \\
\hline
\end{tabular}

Source: Literature survey, 2020

Other Maternal Factors and Child Malnutrition: Maternal Factors belonged to the other category represent $30 \%$ of the reviewed articles that investigated maternal factors according to the figure 2 . 
As shown in the table 12 , there was a relationship between early pregnancy and sever acute malnutrition among their children (Dodos et al., 2018). Ahsan et al. (2017) explored that pregnancy $>4$ times as a significant factor influenced for prevalence of stunting and pregnancy ( $<4$ times) were less likely to be malnourished. According to Rahman and Chowdhury (2007), place of delivery was significantly associated with severe as well as moderate stunting. Further, Ayana et al. (2015) found that nutritional status as measured by wasting was significantly associated with place of delivery. According to Endris et al. (2017), preceding birth interval was independently associated with nutritional status of children in rural Ethiopia. Fagbamigbe et al. (2020) found that nutritional outcome of children was affected by birth interval.

According to Cheah et al. (2010), mothers' family planning was significantly correlated with nutritional status. Oliveira Assis et al. (2008) found that a family headed by a woman was the main determinant of child malnutrition. According to Debnath and Bhattacharjee (2014), women's decisionmaking autonomy was negatively associated with malnutrition. Mothers who are not covered by national health insurance are associated with increased risk of malnutrition among children (Justice Moses et al., 2015).

\section{CONCLUSION}

Many researches have investigated maternal factors and other determinants on child malnutrition and a large volume of publications are available on this. More than $75 \%$ of reviewed research articles on determinants of child malnutrition have analyzed maternal factors. Majority of the reviewed research articles belonged to the immediate last ten years, from 2011 to 2020 . Bivariate or multivariate logistic regression technique have been adopted by most of the studies as a popular approach to fit a model on malnutrition determinants where the dependent variable is with categorical nominal scale, like suffering or not suffering from malnutrition. The sample size was over 300 for $65 \%$ of reviewed articles suggesting a justifiable sample size for reliable interpretation. Maternal factors includes Mothers' Education, Mothers' Breastfeeding practice, Maternal Health, Age of Mother (current age of mother and mother's age at pregnancy), BMI of mother, Mothers' Employability, Mass Media expose of mother, Marital Status, times of pregnancy and early pregnancy, place of delivery, birth interval, family planning, family headed by mother, women's decision-making autonomy and having health insurance. Mothers' Education is the leading factor associated with child malnutrition. From the reviewed research articles that investigated maternal factors, Mothers' Education has been studied by $64 \%$ and for $95 \%$ of them the relationship was found to be significant. Low Education level of mother has increased the risk of having malnutrition among their children. Mothers' Breastfeeding practice was strongly related to the child malnutrition. Increasing the duration of breastfeeding have reduced the likelihood of malnutrition. Maternal Health is too an important variable that interrelates with wealth index to determine child malnutrition and receiving antenatal care by mothers from a health professional causes to reduce the incidence of malnutrition. Younger mothers were more prone to have malnourished children while the opposite was found by some studies. Mothers' BMI, Mass Media expose and Marital Status of mother too established a significant relationship with child malnutrition.

These findings identified that the less attention has been paid by the reviewed studies to the maternal factors related to the school children. Motivating the future researchers is suggested to study the maternal factors and malnutrition focusing school children since they are the immediate group critical for the future labor force that contributes to country development. And also, these finding may direct future researchers and scholars who are interesting in the area and may inform the health sector and other authorities where the effective future intervention should be improved to overcome the incidence of child malnutrition.

\section{REFERENCES}

AHSAN S, MANSOORI N, MOHIUDDIN SM, MUBEEN SM, SALEEM R, IRFANULLAH M.

Ahsan, S., Mansoori, N., Mohiuddin, S. M., Mubeen, S.M., Saleem, R., \& Irfanullah, M. (2017). Frequency and determinants of malnutrition in children aged between 6 to 59 months in district Tharparkar, a rural area of Sindh. Journal of the Pakistan Medical Association, 67(9), 1369-1373

Ali Khan, R. E. \& Azid, T. (2011). Malnutrition in primary school-age children: A case of urban and slum areas of Bahawalpur, Pakistan. International Journal of Social Economics, 38(9), 748-766 https://doi.org/10.1108/03068291111157221

Ayana, A. B., Hailemariam, T.W., \&, Melke, A. S. (2015). Determinants of acute malnutrition among children aged 6-59 months in Public Hospitals, Oromia region, West Ethiopia: a case-control study. BMC Nutrition, 1(34), 1. https://doi.org/10.1186/s40795-015-0031-9

Cheah, W. L., Abdul Manan, W. M. W., \& Zabidi-Hussin, Z. A. M. H. (2010). A structural equation model of the determinants of malnutrition among children in rural Kelantan, Malaysia. Rural and Remote Health, 10(1), 1248.

Chowdhury, T. R., Chakrabarty, S., Rakib, M., Saltmarsh, S., \& Devis, K.A. (2018). Socio-economic risk factors for early childhood underweight in Bangladesh. Global Health, 14(1) 54. https://doi.org/10.1186/s12992-018-0372-7

Cunningham, K., Ruel, M., Ferguson, E., \& Uauy, R. (2015). Women's empowerment and child nutritional status in South Asia: a synthesis of the literature. Maternal and child nutrition, 11(1), 1-19. https://doi.org/10.1111/ mcn.12125

Das, S., \& Gulshan, J. (2017). Different forms of malnutrition among under five children in Bangladesh: a cross sectional study on prevalence and determinants. BMC Nutr 3(1), 1, https://doi.org/10.1186/s40795-016-0122-2

Dasa, J. K., Lassib, Z. S., Hoodbhoya, Z.., \& Salama, R. A. (2018). Nutrition for the Next Generation: Older Children and Adolescents. Ann Nutr Metab, 72(3), 56-64, https://doi.org/10.1159/000487385

Debnath, A., \& Bhattacharjee, N. (2014). Factors Associated with Malnutrition among Tribal Children in India: A Non-Parametric Approach. Journal of Tropical Pediatrics, 60(3), 211215. https://doi.org/10.1093/tropej/fmt106

Demissie, S., \& Worku, A. (2013). Magnitude and Factors Associated with Malnutrition in Children 6-59 Months of Age in Pastoral Community of Dollo Ado District, Somali Region, Ethiopia. Science Journal of Public Health, 1(4), 175-183. https://doi.org/ 10.11648/j.sjph.20130104.12

Dodos, J., Altare, C., Bechir, M., Miyatt, M., Pedro, B., Bellet, F., ... Altmann, M. (2018). Individual and household risk factors of severe acute malnutrition among under-five children in Mao, Chad: a matched case-control study. Arch Public Health, 76(1), 35. https://doi.org/ 10.1186/ s13690-018-0281-5

Duru, C. B., Oluoha, U. R., Uwakwe, K. A., Diwe, K. C., Merenu, I. A., Chigozie, I.O., \& Iwu, A.C. (2015). Prevalence and Sociodemographic Determinants of Malnutrition among Under-Five Children in Rural Communities in Imo State, Nigeria. American Journal of Public Health Research, 3( 6), 199-206. https://doi.org/10.12691/ajphr-3-6-1.

Endris, N., Asefa, H., \& Dube, L. (2017). Prevalence of Malnutrition and Associated Factors among Children in Rural Ethiopia. BioMed Research International, 2017:6 https://doi.org/10.1155/2017/6587853

Fagbamigbe, A.F., Kandala, N.B., \& Uthman, A.O. (2020). Demystifying the factors associated with rural-urban gaps in severe acute malnutrition among under-five children in low- and middle-income countries: a decomposition analysis. Sci Rep, 10, 1-15, 11172, https://doi.org/10.1038/s41598-020-67570-w 
Galgamuwa, L.S., Iddawela, D., Dharmaratne, S.D., \& Galgamuwa, G.L.S. (2017). Nutritional status and correlated socio-economic fac tors among preschool and school children in plantation communities, Sri Lanka. BMC Public Health, 17, 377 https://doi.org/10.1186/s12889-017-4311-y

Ge, K.Y., \& Chang, S.Y. (2001). Definition and measurement of child malnutrition. Biomedical and Environmental Sciences: BES, 14(4), 283 291.

Gebre, A., Reddy, P.S., Mulugeta, A.Y., \& Kahssay, M., (2019). Prevalence of Malnutrition and Associated Factors among Under-Five Children in Pastoral Communities of Afar Regional State, Northeast Ethiopia: A Community-Based Cross-Sectional Study. Journal of Nutrient and Metabolism, 2019, 13, Article ID 9187609 https://doi.org/10.1155/2019/9187609

Getaneh, Z., Melku, M., Geta, M., Melak, T., \& Hunegnaw, M. T. (2019) Prevalence and determinants of stunting and wasting among public primary school children in Gondar town, northwest, Ethiopia. BMC Pediatr, 19,(1), 1-11. https://doi.org/10.1186/s12887-0191572-x

Ghimire, U., Aryal, B.K., Gupta, A.K., \& Sapkota, S. (2020). Severe acute malnutrition and its associated factors among children under-five years: a facility-based cross-sectional study. BMC Pediatr, 20 (1), 1-9, https://doi.org/10.1186/s12887-020-02154-1

gohavacyf (Blog), 2020. EMPIRICAL LITERATURE REVIEW MEANNING IN RESEARCH WRITING Retrieved on 29.03.2021 from https://gohavacyf.wordpress.com/2020/04/03/empirical-literature-review-meaning-in-research-writing/

Habyarimana, F., Zewotir, T., \& Ramroop, S. (2016). Key determinants of malnutrition of children under five years of age in Rwanda: simultaneous measurement of three anthropometric indices. African Population Studies, 30(2), 2328-2340. http://dx.doi.org/10.11564/30-2 836

Hannah R.A, Sekarwana, N., \& Effendi, S.H. (2017). Prevalence of Moderate Malnutrition in School-age Children and Its Association with Hypertension and Microalbuminuria. American Journal of Clinical Medicine Research, 5(1), 6-9 http://pubs.sciepub.com/ajcmr/5/1/2 DOI:10.12691/ajcmr-5-1-2

Hossain, A., Niroula, B., Duwal, S., Ahmed, S., \& Kibria, M.G. (2020). Maternal profiles and social determinants of severe acute malnutrition among children under-five years of age: A case-control study in $\mathrm{Ne}-$ pal. Heliyon, 6(5). https://doi.org/10.1016/j.heliyon.2020.e03849

Igbokwe, O., Adimorah, G., Ikefuna, A., Ibeziako, N., Ubesie, A., Ekeh, C., \& Iloh, K. (2017). Socio-demographic determinants of malnutrition among primary school aged children in Enugu, Nigeria. Pan African $\begin{array}{lll}\text { Medical Journal, 28(1), } & \end{array}$ https://doi.org/10.11604/pamj.2017.28.248.13171

Jayawardena, P. (2015). Socio-economic determinants and inequalities in childhood malnutrition in Sri Lanka. Well-Being and Social Policy Journal, 8 (1), 1-22.

Aheto, J.M.K., Keegan, T.J., Benjamin M., Taylor, B.M., \& Diggle, P.J. (2015). Childhood Malnutrition and Its Determinants among UnderFive Children in Ghana. Paediatric and Perinatal Epidemiology, 29(6), 552-561. https://doi.org/10.1111/ppe.12222

Kabir, M. R., Rahman, M., Mamun, M. A., \& Islam, H. (2018). Prevalence of malnutrition and associated factors affecting the nutritional status of Adivasi (tribal) children aged 24-59 months in Bangladesh. Asian Journal of Medical and Biological Research, 4(2), 178-185 https://doi.org/10.3329/ajmbr.v4i2.38253

Kandala, N., Madungu, T.P., Emina, J.B.and et al. (2011). Malnutrition among children under the age of five in the Democratic Republic of Congo (DRC): does geographic location matter?. BMC Public Health 11: 261. https://doi.org/10.1186/1471-2458-11-261

Keerthiwansa, J., Gajealan, S., Sivaraja, S., \& Subashiniv, K.Y, (2014), Malnutrition and anaemia among hospitalised children in Vavuniya. CeyIon Medical Journal, 59( 04), 141-143

Khan, J., \& Mohanty, S.K. (2018). Spatial heterogeneity and correlates of child malnutrition in districts of India. BMC Public Health, 18, 1027, 1 13. https://doi.org/10.1186/s12889-018-5873-

Knopf, J. (2006). Doing a Literature Review. PS: Political Science and Politics, 39(1), 127-132.

Kulaga, Z., Litwin, M., Tkaczyk, M., Różdżyńska, A., Barwicka, K., Grajda,
A.,... Pan, H. (2010). The height-, weight-, and BMI-for-age of Polish school-aged children and adolescents relative to international and local growth references. BMC Public Health, 10, 109. https://doi.org/10.1186/1471-2458-10-109

Linnemayr, S., Alderman H, \& Ka, A. (2008). Determinants of malnutrition in Senegal: Individual, household, community variables, and their interaction. Economics \& Human Biology, 6(2), 252-263, https:// doi.org/ 10.1016/ j.ehb.2008.04.003

Magalhães, R.J.S., \& Clements, A.C.A. (2011). Mapping the Risk of Anaemia in Preschool-Age Children: The Contribution of Malnutrition, Malaria, and Helminth Infections in West Africa. PLoS Med, 8(6), e1000438. https://doi.org/10.1371/journal.pmed.1000438

McCombes, S (2019). How to write a literature review: Retrieved on 29.03.2021 from https://www.scribbr.com/dissertation/literaturereview

Mustari, S., Hossain, I., Khatun, K., Ali, M.S., Rahman, H., Mondal, A., ... Islam, S. (2017). Prevalence and Determinants of Malnutrition among Poor Women and Children in the South-West Region of Bangladesh. IOSR Journal of Pharmacy and Biological Sciences, 13(4), 62-69 www.iosrjournals.org DOI: 10.9790/3008-1304036269

Oliveira Assis, A., Barreto, M. L., de Oliveira, L. M., De Oliveira, V., Da Silva P. M., Gomes, G.D.S., ..., Santos, L. P. (2008). Determinants of mild-to-moderate malnutrition in preschoolers in an urban area of Northeastern Brazil: A hierarchical approach. Public Health Nutrition 11(4), 387-394. doi:10.1017/S1368980007000390

Pravana, N.K., Piryani, S., Chaurasiya S.P., Kawan, R., Thaoa, R.K., \& Shresta, S., (2017), Determinants of severe acute malnutrition among children under 5 years of age in Nepal: a community-based case-control study, BMJ Open, 7(8), http://dx.doi.org/10.1136/ bmjopen2017-0170

Rahman, A., \& Chowdhury, S. (2007). Determinants of Chronic Malnutrition among pre-school children in Bangladesh. Journal of Biosocial Science, 39(02), 161-173 doi:10.1017/S0021932006001295

Rahman, A., Chowdhury, S., \& Hossain, D. (2009). Acute Malnutrition in Bangladeshi Children: Levels and Determinants. Asia Pacific Journal of Public Health (APJPH), 21(3), 294-302 https://doi.org/ 10.1177/ 1010539509335399

Rathnayake, I.M., \& Weerahewa, J. (2005). Determinants of Nutritional Status among Pre-School Children in Sri Lanka. Tropical Agricultural Research, 17:148-161

Sargana, S.I., \& Mohyuddin, A. (2013). Malnutrition among school going children in Pakistan. Indian Journal of Health and Wellbeing, 4(9), 1654-1659.

Tette, E.M.A., Sifah, E.K., Nartey, E.T., Nuro-Ameyaw, p., Tete-Donkor, P., \& Biritwum, R.B. (2016). Maternal profiles and social determinants of malnutrition and the MDGs: What have we learnt?.BMC Public Health, 16(1), 214. https://doi.org/10.1186/s12889-016-2853-z

Ubeysekara, N.H., Jayathissa, R., \& Wijesinghe C.J. (2015). Nutritional Status and Associated Feeding Practices among Children Aged 6-24 Months in a Selected Community in Sri Lanka: A Cross Sectional Study. European Journal of Preventive Medicine, 3(2-1), 15-23. doi: 10.11648/j.ejpm.s.2015030201.14

World Health Organization, [WHO], (2020). Malnutrition, Retrieved on 26.07.2020 from https://www.who.int/ news-room/fact-sheets/detail//malnutrition

Yadav, A., \& Dixit, A. (2017). A study to assess the prevalence of malnutrition among under 5 year children at selected Anganwadi centres of Jaipur district. Medical Science Journal, 3(11), 78-79.

Zhang, N., Bécares, L., \& Chandola, T. (2016). Patterns and Determinants of Double-Burden of Malnutrition among Rural Children: Evidence from China. PloS one, 11, e0158119. https://doi.org/10.1371/journal.pone.0158119 